Gut, 1966, 7, 333

\title{
Cell loss from human gastric mucosa measured by the estimation of deoxyribonucleic acid (DNA) in gastric washings
}

\author{
D. N. CROFT ${ }^{1}$, D. J. POLLOCK, AND N. F. COGHILL \\ From the West Middlesex Hospital, Isleworth, Middlesex
}

The epithelium of the gastrointestinal tract is constantly being replaced (Bizzozero, 1892, 1893; Friedman, 1945; Bertalanffy and Nagy, 1958) and this is a continuous physiological process (Leblond and Messier, 1958; Creamer, Shorter, and Bamforth, 1961). Gastric surface epithelial and mucous neck cells divide frequently, although the rate of division may be slower in the latter (Stevens and Leblond, 1953). Parietal and chief cells, if they divide at all, do so much more slowly (MacDonald, Trier, and Everett, 1964). In the human stomach surface epithelial cells are formed at the bottom of the gastric pits and migrate up the wall of the pits to reach the surface of the mucosa in two to six days (Lipkin, Sherlock, and Bell, 1963; MacDonald et al., 1964). At the surface they degenerate (Leblond and Stevens, 1948) and are probably shed into the lumen of the stomach in a similar manner to that observed in the small bowel (Stevens and Leblond, 1953; Creamer et al., 1961).

In the resting state an equilibrium should exist between the rate of production and the rate of loss of surface epithelial cells (Stevens and Leblond, 1953; Crosby, 1961). This paper describes a method of measuring the resting rate of accumulation of cells in the gastric lumen which, we suggest, represents the rate of loss of cells from the gastric mucosa. We further suggest that this rate of loss is related to the rate of production of gastric surface epithelial cells.

The cellular content of gastric washings was measured by estimating their deoxyribonucleic acid (DNA) content. As DNA is present in nuclei only and as there is a fairly constant amount in each human somatic cell nucleus (Davidson, Leslie, and White, 1951), the quantity in a gastric washing is proportional to the number of cells present. Previous work in man appeared to show that constant small amounts of DNA were obtained in repeated saline gastric washings (Croft, 1963b). It

${ }^{1}$ In receipt of a grant from the Medical Research Council. Present address: St. Thomas' Hospital, London, S.E.1. was thought that such DNA might represent the natural loss of cells from the gastric mucosa. In order to investigate this further the technique for obtaining the gastric washouts was altered and a more sensitive method for estimating DNA (Burton, 1956) was modified to prevent interference from sialic acid present in mucus (Croft and Lubran, 1965).

\section{MATERIALS AND METHODS}

GASTRIC PERFUSION TUBE Three holes of $1.0 \times 0.3 \mathrm{~cm}$. size were made near the tip of a plastic Ryle's tube (internal diameter $4.0 \mathrm{~mm}$.). A polythene catheter (internal diameter $2.0 \mathrm{~mm}$.) was attached along the length of this tube so that one end of the catheter opened $9.5 \mathrm{~cm}$. from its uppermost hole (Figure 1.)

REAGENTS Sodium ethylenediamine tetra-acetate (E.D.T.A.) was used to inactivate deoxyribonucleases (Marmur, 1961), and 0.2M E.D.T.A. at $p \mathrm{H} 8$ was added to each washout specimen to give a final concentration of approximately $\mathrm{M} / 100$.

Sodium chloride solution $(0.9 \mathrm{g.} \%)$ used for the washings contained $0.8 \mathrm{mg}$. polythelene glycol (M.W.
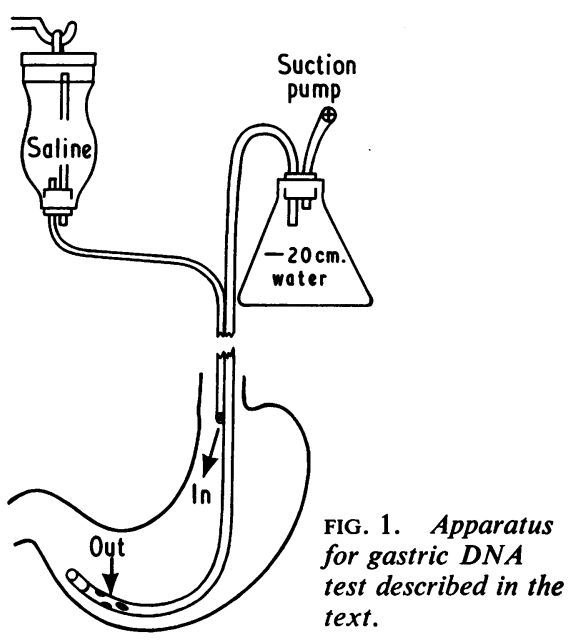
4000) per $\mathrm{ml}$. It was intended to use this as an unabsorbable marker of infused saline (Hyden, 1965; Borgström, Dahlqvist, Lundh, and Sjövall, 1957) but this was unnecessary as recovery was virtually complete in most cases and the application of a correction factor based on the volume recovered (see below) was subsequently found to be more accurate than one based on polyethylene glycol recovery. Polyethylene glycol did not interfere with the chemical estimation of DNA.

Standard DNA solution containing $836 \mathrm{~m} \mu \mathrm{g}$. atoms phosphorus per ml. was prepared by dissolving $40 \mathrm{mg}$. of highly polymerized calf thymus DNA (Sigma) in $100 \mathrm{ml} .5 \mathrm{mM} \mathrm{NaOH}$ and stored at $4^{\circ} \mathrm{C}$.

GASTRIC PERFUSION TECHNIQUE Tests were performed in the morning after the patient had fasted 12 to 15 hours. Under fluoroscopy the tip of the gastric perfusion tube was adjusted so that it lay over the left edge of the supine patient's vertebral column. A dental sucker was placed in the mouth and the patient asked not to cough, swallow, or retch during the test. No drugs were given. The $p H$ of the gastric fluid was measured using narrow range $p \mathrm{H}$ paper. The fasting gastric washout ('first specimen') was obtained by injecting and withdrawing by syringe $500 \mathrm{ml}$. of warm $\left(29\right.$ to $\left.35^{\circ} \mathrm{C}\right)$ saline in $1050 \mathrm{ml}$. fractions while rotating the patient to the right and left from the supine position. Eight of the $50 \mathrm{ml}$. fractions were injected and withdrawn through the Ryle's tube. In order to wash out the cardia two fractions were injected down the polythene catheter and withdrawn through the Ryle's tube. The time was noted and the polythene catheter at once attached through a disposable transfusion set to $500 \mathrm{ml}$. of warm saline suspended approximately $80 \mathrm{~cm}$. above the tip of the catheter (Figure 1). The flow of saline was started by a bellows. The Ryle's tube was attached through a suction pump (pressure minus 15 to $20 \mathrm{~cm}$. of water) to a litre-sized bottle containing $25 \mathrm{ml}$. of the 0.2M E.D.T.A. solution. By adjusting the supine patient's position a continuous return flow was obtained from the Ryle's tube. If satisfactory flow was not obtained or if there was bile in the specimen the tube was withdrawn about an inch. Precautions were taken to prevent the end of the polythene catheter being withdrawn into the oesophagus. Saline, $500 \mathrm{ml}$., was perfused through the stomach and aspirated over a timed period to yield the 'second specimen'. By the use of a Y-tube connexion two further bottles of $500 \mathrm{ml}$. of saline were perfused to give the 'third and fourth specimens'. The specimens were placed in ice immediately.
CYTOLOGY Specimens for cytological examination were obtained either during aspiration from a glass sedimenting chamber attached to the Ryle's tube, or more commonly, from the particles which had settled to the bottom of the bottle while being cooled in ice. Particles were floated on to a slide, fixed in $95 \%$ ethyl alcohol, and stained with haematoxylin and eosin.

RECOVERY OF INFUSED SALINE The average volume recovered in the 33 specimens to be reported was $93 \%$ of the volume infused. In three specimens it was less than $80 \%$ and in one $112 \%$. Absorption of saline and secretion of gastric juice could have had little effect on the volumes recovered because each perfusion took only 10 to 19 minutes (average 13.5) and the perfusing volume was large $(500 \mathrm{ml}$.).

RATE OF ACCUMULATION OF DNA IN THE STOMACH The DNA in the whole of each gastric washing was precipitated, extracted, and estimated in duplicate by the method of Croft and Lubran (1965). Duplicate estimations differed by less than $\pm 3 \%$ of their means. The DNA values were related to the amount of phosphorus in the standard solution of DNA and were expressed as $\mathrm{m} \mu \mathrm{g}$. atoms of DNA-P.

The DNA content of the second, third, and fourth specimens was corrected for the difference between the volume of saline infused and the volume of fluid recovered by multiplying it by volume infused/volume recovered. This value was divided by the duration (in minutes) of the perfusion for the respective specimen, to yield the rate of accumulation of DNA in the stomach.

GASTRIC DNA RATE The first specimen in all tests contained large amounts of DNA which arose from gastric and respiratory cells which had accumulated in the stomach before the start of the test (Croft, 1963b). Much lower DNA values were found in subsequent specimens, particularly if the patient did not cough, retch, or swallow. The lowest rate of accumulation of DNA for each test was considered to measure DNA loss from the gastric mucosa and was designated the gastric DNA-rate. Gastric DNA-rates measured on two occasions separated by five to 15 weeks on each of four patients were within \pm $10 \%$ of their means (Table I).

NON-GASTRIC DNA Contamination of gastric washings with DNA from material other than cells lost from the gastric mucosa could have occurred from swallowed material, duodenal reflux, or DNA-containing bacteria.

TABLE I

RESULTS OF REPEATED GASTRIC PERFUSION TESTS PERFORMED ON FOUR PATIENTS

\begin{tabular}{|c|c|c|c|c|c|}
\hline \multirow[t]{2}{*}{$\begin{array}{l}\text { Patient } \\
\text { No. }\end{array}$} & \multirow[t]{2}{*}{ Clinical Group } & \multirow{2}{*}{$\begin{array}{l}\text { Interval between } \\
\text { Tests } \\
\text { (weeks) }\end{array}$} & \multicolumn{3}{|c|}{$\begin{array}{l}\text { Gastric DNA Rates } \\
\text { (mug. atoms DNA-P/minute) }\end{array}$} \\
\hline & & & First Test & Second Test & Mean \\
\hline $\begin{array}{r}4 \\
11 \\
13 \\
24\end{array}$ & $\begin{array}{l}\text { Normal mucosa } \\
\text { Normal mucosa } \\
\text { Pernicious anaemia } \\
\text { Simple atrophic gastritis }\end{array}$ & $\begin{array}{r}11 \\
5 \\
19 \\
15\end{array}$ & $\begin{array}{r}12 \\
52 \\
6 \\
73\end{array}$ & $\begin{array}{r}12 \\
42 \\
5 \\
71\end{array}$ & $\begin{array}{r}12 \\
47 \\
6 \\
72\end{array}$ \\
\hline
\end{tabular}


Swallowed material To assess the order of contamination from DNA in swallowed saliva and sputum, four patients collected these secretions over timed intervals of 15 to 30 minutes. The DNA content of the material was converted into a secretion rate (Table II). The results indicated that DNA in saliva and sputum, if swallowed, could have increased the lowest gastric DNA-rates by $300 \%$ to $1,000 \%$. For this reason a mouth sucker was used and patients with persistent cough and sputum were excluded.

\section{TABLE II}

DNA IN SALIVA AND SPUTUM FROM FOUR PATIENTS

DNA Secretion Rate (mug. atom DNA-P/min.)

Saliva

Resting

13

Stimulated with acid drop

53

Sputum

Mucoid (patient with asthma)

53

Purulent (patient with pneumonia)

640

Cytological examination indicated that the DNA arose mainly from cells lost from the gastric mucosa. Squamous cells were seen in some specimens, and appeared to be more resistant to the action of gastric juice (Tomenius, 1947) than gastric epithelial cells. For this reason squamous cells were probably more conspicuous cytologically than quantitatively important as a source of DNA. As some DNA arose from totally destroyed cells and nuclei and as only a small volume of each $500 \mathrm{ml}$. specimen was examined, cytology was not an entirely satisfactory method of assessing the amount of contamination with non-gastric DNA.

Duodenal reflux Contamination by duodenal secretions was assessed by noting bile discoloration of the aspirates. This was not present in any specimens from which gastric DNA rates were calculated.

Bacteria Some types of bacteria contain DNA. Bacteria were probably present in the patients with pernicious anaemia (Hurst, 1924; Dick, 1941; Schade, 1960). In our patients with this condition low gastric DNA rates were found which suggested that DNA from bacteria was either quantitatively unimportant, or was removed in the first washing.

The reproducibility of gastric DNA rates even at the lowest values (Table I) suggested that contamination with non-gastric DNA was unimportant. It was unlikely that contamination would have been the same on two separate occasions in each of the four subjects, and Nordgren (1963) prevented contamination of gastric secretions with saliva and duodenal contents by methods similar to those we adopted.

GASTRIC BIOPSY Gastric biopsy was usually done within six weeks of the gastric DNA test using a modified Australian gastric biopsy tube (Wood, Doig, Motteram, and Hughes, 1949; Coghill and Williams, 1955). In cases $12,14,20,27$, and 28 it was performed between 21 months and 11 years previously. Between one and four specimens (average three) were obtained from each of 27 patients. The biopsy specimens were placed mucosal surface uppermost on duplicating paper and fixed within two minutes in $10 \%$ formalin solution. Sections were cut at $6 \mu$ and stained with haematoxylin and eosin and by the Feulgen method. Histological examination was made by one observer (D.J.P.) without knowledge of the clinical data or test results. The appearances were classified as follows:-

Normal, including minor miscellaneous mucosal changes (Williams, Edwards, Lewis and Coghill, 1957).

Atrophic gastritis, grade I, atrophy of up to $50 \%$ of the gastric body glands.

Atrophic gastritis, grade II, atrophy of 50 to $90 \%$ of the gastric body glands.

Atrophic gastritis, grade III, atrophy of 90 to $100 \%$ of the gastric body glands.

Particular features of the gastric biopsy specimens are shown in Table III.

MITOSIS counTs Mitosis counts were performed on the Feulgen-stained gastric biopsy sections, areas in which a gastric gland was cut perpendicularly along its full length being chosen. Epithelial cells were counted from the opening of the gland, down to its lower limit and up the other side to the surface. All mitoses were recorded except early prophases and late telophases. When possible a total of 2,000 cells were counted. The biopsy was generally discarded if, because of bad orientation of the section, less than 1,000 suitable cells could be counted. In some specimens only areas of intestinal metaplasia provided satisfactory sites for counting. There were no differences in the thickness of metaplastic areas in patients with simple atrophic gastritis and pernicious anaemia.

AUGMENTED HISTAMINE TESTS These were performed (Kay, 1953) on patients with pernicious anaemia and on those in whom the $p \mathrm{H}$ of a sample of resting gastric juice was above 3.5 using narrow range $p \mathrm{H}$ paper. The tip of a Ryle's tube was placed in the stomach by fluoroscopy as described above and $75 \mathrm{mg}$. of mepyramine maleate was given. The $p \mathrm{H}$ of the gastric juice was measured electrometrically.

GASTRIC ANTIBODIES Autoantibody tests were kindly performed by Drs. D. Doniach and I. M. Roitt (Middlesex Hospital). Parietal cell antibodies were detected by immunofluorescence (Taylor, Roitt, Doniach, Couchman, and Shapland, 1962), and the titres determined by complement fixation (Irvine, Davies, Delamore and Williams, 1962; Baur, Roitt, and Doniach, 1965). Antibodies to gastric intrinsic factor were demonstrated by the electrophoretic retention test (Jeffries, Hoskins, and Sleisenger, 1962; Taylor et al., 1962) and by the vitamin $\mathrm{B}_{12}$ charcoal-binding reaction (Ardeman and Chanarin. 1963).

SECRETOR STATUS Samples of saliva were heated at $100^{\circ} \mathrm{C}$. for $10 \mathrm{~min}$., and stored at minus 16 to minus $20^{\circ} \mathrm{C}$. Dr. M. J. A. Langman (Guy's Hospital) kindly analysed the specimens for blood group substances (Boyd and Shapleigh, 1954; Clarke, Edwards, Haddock, HowelEvans, McConnell, and Sheppard, 1956; Doll, Drane, and Newell, 1961). 
TABLE III

CLINICAL AND LABORATORY DETAtLS OF 28 PATIENTS ON WHOM GASTRIC DNA TESTS WERE PERFORMED

\begin{tabular}{|c|c|c|c|c|c|c|c|c|c|c|c|c|c|c|c|}
\hline \multicolumn{4}{|c|}{ Clinical } & \multicolumn{2}{|c|}{ Secretor Status } & \multirow{2}{*}{\multicolumn{3}{|c|}{$\frac{\text { Gastric Antibodies }}{\text { Parietal Cell }}$}} & \multirow{3}{*}{$\begin{array}{l}\text { Gastric } \\
\text { pH } \\
\text { (lowest } \\
\text { value) }\end{array}$} & \multicolumn{5}{|c|}{ Gastric Biopsy } & \multirow{2}{*}{$\begin{array}{l}\text { Gastric } D N A \\
\text { rate }\end{array}$} \\
\hline Case & Sex & Age & Clinical & Blood & Secretor & & & & & Histo- & Regular $(R)$ & Inflamma- & Intest- & Mitoses & \\
\hline & & & & & & $\begin{array}{l}\text { Immuno- } \\
\text { fluore- } \\
\text { scent }\end{array}$ & $\begin{array}{l}\text { Comple- } \\
\text { ment } \\
\text { Fixation }\end{array}$ & $\begin{array}{l}\text { Intrin- } \\
\text { sic } \\
\text { Factor }\end{array}$ & & $\begin{array}{l}\text { Assess- } \\
\text { ment }\end{array}$ & $\begin{array}{l}\text { (I) Surface } \\
\text { Epithelium }\end{array}$ & $\begin{array}{l}\text { Penetrating } \\
\text { Epithelium }\end{array}$ & $\begin{array}{l}\text { Meta- } \\
\text { plasia }\end{array}$ & $\begin{array}{l}\text { Surface } \\
\text { Epithelial } \\
\text { Cells }\end{array}$ & \\
\hline
\end{tabular}

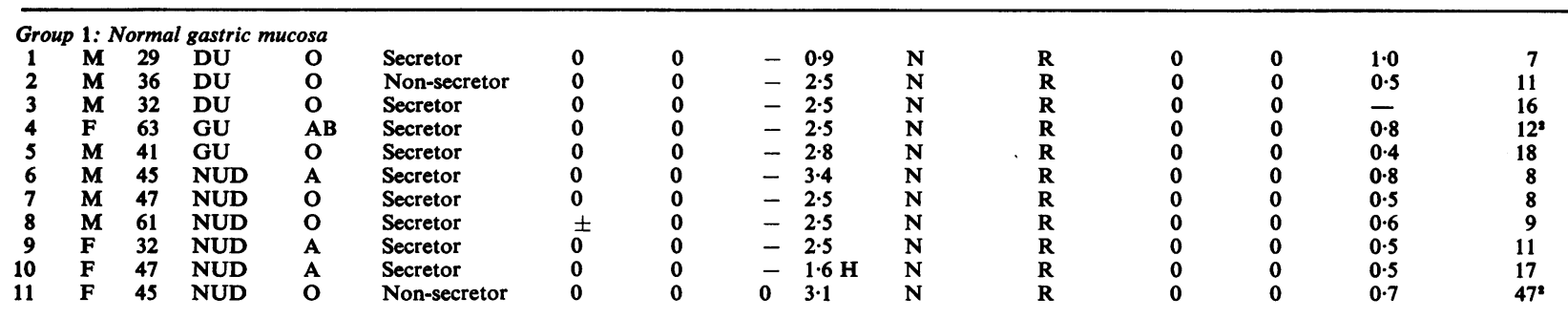

Group 2: Treated Addisonian pernicious anaemia

$\begin{array}{llll}12 & \text { F } & 58 & \\ 13 & \text { F } & 62 & \\ 14 & M & 54 & \text { A } \\ 15 & \text { F } & 64 & \text { A } \\ 16 & \text { M } & 55 & \text { A } \\ 17 & \text { M } & 40 & \text { A } \\ 18 & \text { M } & 72 & \text { A } \\ 19 & \text { F } & 46 & \text { M } \\ 20 & 69 & \end{array}$

$\begin{array}{ll}\text { O } & \text { Secretor } \\ \text { A } & \text { Secretor } \\ \text { A } & \text { Non-secretor } \\ \text { A } & \text { Secretor } \\ \text { A } & \text { Secretor } \\ \text { O } & - \\ \text { A } & \text { Secretor } \\ \text { A } & \text { Secretor } \\ \text { A } & \text { Secretor }\end{array}$

$\begin{array}{ll}+ & 1 / 8 \\ + & 1 / 4 \\ + & 1 / 4 \\ + & 0 \\ + & 1 / 4 \\ + & 0 \\ + & 1 / 8 \\ + & 0 \\ + & 1 / 8\end{array}$

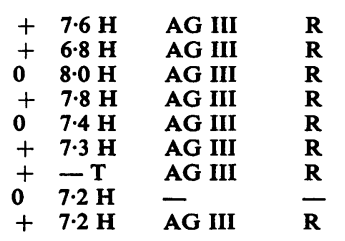

\begin{tabular}{ccc}
0 & 0 & 1.0 \\
+ & 0 & 1.0 \\
+ & + & 1.8 \\
0 & + & 1.4 \\
0 & + & $2.0^{3}$ \\
0 & + & $1.6^{1}$ \\
0 & 0 & 1.0 \\
\hline 0 & - & -
\end{tabular}

Group 3: Simple atrophic gastritis

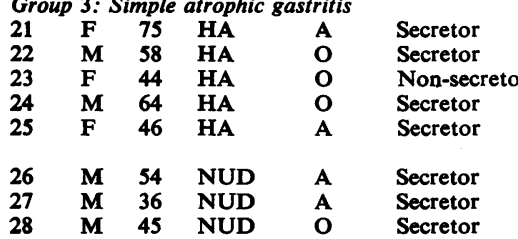

$\begin{array}{ll}0 & 0 \\ + & 1 / 8 \\ + & 1 / 128 \\ 0 & 0 \\ + & 1 / 4 \\ 0 & 0 \\ 0 & 0 \\ 0 & 0\end{array}$

$\begin{array}{ll}\mathbf{0} & 1.5 \mathrm{H} \\ \mathbf{0} & \mathbf{7 . 0} \mathbf{H} \\ \mathbf{0} & \mathbf{7 . 2} \mathbf{H} \\ \mathbf{0} & \mathbf{5 . 3} \mathbf{H} \\ \mathbf{0} & \mathbf{2 . 0} \mathbf{H} \\ & \\ \mathbf{0} & \mathbf{2 . 0} \mathbf{H} \\ \mathbf{0} & \mathbf{2 . 5} \\ \mathbf{0} & \mathbf{6 . 9} \mathbf{H}\end{array}$

$\begin{array}{ll}\text { AG II } & \text { R } \\ \text { AG III } & \text { R } \\ \text { AG III } & \text { R } \\ \text { AG III } & \text { I } \\ \text { AG I } & \\ \text { \& II } & \text { I } \\ \text { AG III } & \text { I } \\ \text { AG I } & \text { R } \\ \text { AG I } & \\ \text { \& II } & \text { I }\end{array}$

\footnotetext{
Normal

NUD Non-ulcer dyspepsia

GU Gastric ulcer

DU Duodenal ulcer

HA Hypochromic anaemia

H After maximal histamine stimulation

T Tubeless test meal indicated achlorhydria after maximal histamine stimulation

1 Mean of counts in gastric area and area of intestinal metaplasia (Fig. 8).

Mean of two tests (Table I)

Count in area of intestinal metaplasia

- This patient also had a test before treatment with vitamin $\mathbf{B}_{12}$ (Fig 3).
}

haEMATOLOGICAL INVESTigations Blood group and haemoglobin estimations were performed on all patients. Serum $B_{12}$ concentrations were measured by the method described by Hutner, Bach, and Ross (1956) and radioactive vitamin $B_{12}$ absorption was measured by the faecal method of Booth and Molin (1956), by the method described by Schilling (1953), by the hepatic uptake method (Glass, Boyd, Gellin, and Stephanson, 1954), or by the technique of whole body counting (Belcher, Anderson, and Robinson, 1963).

\section{SUBJECTS EXAMINED}

The nature of the studies was explained to the patients who agreed to them. The 28 subjects on whom 33 tests were performed fell into three categories (Table III).

PATIENTS WITH NORMAL GASTRIC MUCOSA Eleven patients (seven males and four females), mean age 44 years (range 29 to 63), had normal gastric mucosa on biopsy. Six of these had dyspepsia with a normal barium meal (nonulcer dyspepsia), three a duodenal ulcer, one a prepyloric ulcer and one a small lesser curve gastric ulcer. In all, the $p \mathrm{H}$ of resting or post-histamine gastric juice was below 3.5 . All had a haemoglobin above $12.0 \mathrm{~g} . \%$. Most of the patients were free of symptoms at the time of the gastric DNA test.

PATIENTS WITH PERNICIOUS ANAEMIA Nine patients 
(five males and four females), mean age 58 years (range 40 to 72 ), had Addisonian pernicious anaemia. The pretreatment serum $B_{12}$ level was below $60 \mu \mu \mathrm{g} . / \mathrm{ml}$., in the eight patients in whom it was estimated. In all nine radioactive vitamin $B_{12}$ absorption was within the range found in Addisonian pernicious anaemia when the dose was given alone or with carbachol and rose to normal levels when the dose was given with intrinsic factor. The histological features of the gastric mucosa are shown in Table III. The gastric biopsy tube could not be passed in case 19 who was achlorhydric. In six patients the $p \mathrm{H}$ of the gastric juice rose after maximal histamine stimulation, and in all cases was between 6.8 and 8.0 . Case 18 had a tubeless augmented histamine test using Diagnex blue (Squibb); no dye was excreted in the urine, indicating achlorhydria. Five of the patients (cases 12, 14, 16,18 , and 20) had a barium meal and in each the appearances of gastric atrophy were seen (Laws and Pitman, 1960) Gastric DNA tests were performed on one patient (case 19) before treatment and on all when they had been treated with vitamin $\mathrm{B}_{12}$ for six weeks to 11 years, and their haemoglobin was over $11.0 \mathrm{~g} . \%$.

PATIENTS WITH SIMPLE ATROPHIC GASTRITIS Eight patients (five males and three females), mean age 53 years (range 36 to 75), had simple atrophic gastritis (grades I to III) diagnosed by gastric biopsy (Table III). These patients did not have pernicious anaemia and had no family history of it. Five of them had suffered from hypochromic anaemia and three from non-ulcer dyspepsia. Four of these patients secreted gastric $\mathrm{HCl}$ (Table III). Of the other four, in two the $\mathrm{pH}$ rose, in one it remained the same (6.9), and in one it fell from 5.8 to 5.3 after histamine. The serum $B_{12}$ concentration was $170 \mu \mu \mathrm{g}$. $/ \mathrm{ml}$. or above in seven of the patients. Measurements of radioactive vitamin $\mathbf{B}_{12}$ absorption in cases 2125,27 , and 28 indicated that they were not suffering from pernicious anaemia; case 26 was not tested but secreted gastric HC1. One patient (case 22) with hypochromic anaemia (corrected by oral iron without the development of macrocytosis), had a gastric juice $p \mathrm{H}$ of 7.0 after maximal histamine stimulation, grade III atrophic gastritis, and a serum $B_{12}$ level of $95 \mu \mu \mathrm{g} . / \mathrm{ml}$. This patient (tested by the method of whole body counting) absorbed $0 \cdot 14 \mu \mathrm{g}$. of an oral dose of $1 \mu \mathrm{g}$. radio- $\mathrm{B}_{12}$ given alone, $0 \cdot 27 \mu \mathrm{g}$. when the dose was given with Carbachol, and $0.47 \mu \mathrm{g}$. when the dose was given with intrinsic factor; he resembled patients with simple atrophic gastritis described by Wood, Ralston, Ungar, and Cowling (1964) and by Whiteside, Mollin, Coghill, Williams, and Anderson (1964), and has not developed pernicious anaemia during 18 months of observation. All but one (case 21) had a barium meal. In four it was normal; in three (cases 22, 23, and 25) it showed the appearances of gastric atrophy (Laws and Pitman, 1960). At the time of the gastric DNA test the haemoglobin in these patients was more than $10.0 \mathrm{~g} . \%$.

\section{RESULTS}

GASTRIC DNA-RATES IN THE THREE CLINICAL GROUPS The results of 28 gastric DNA-rate determinations,

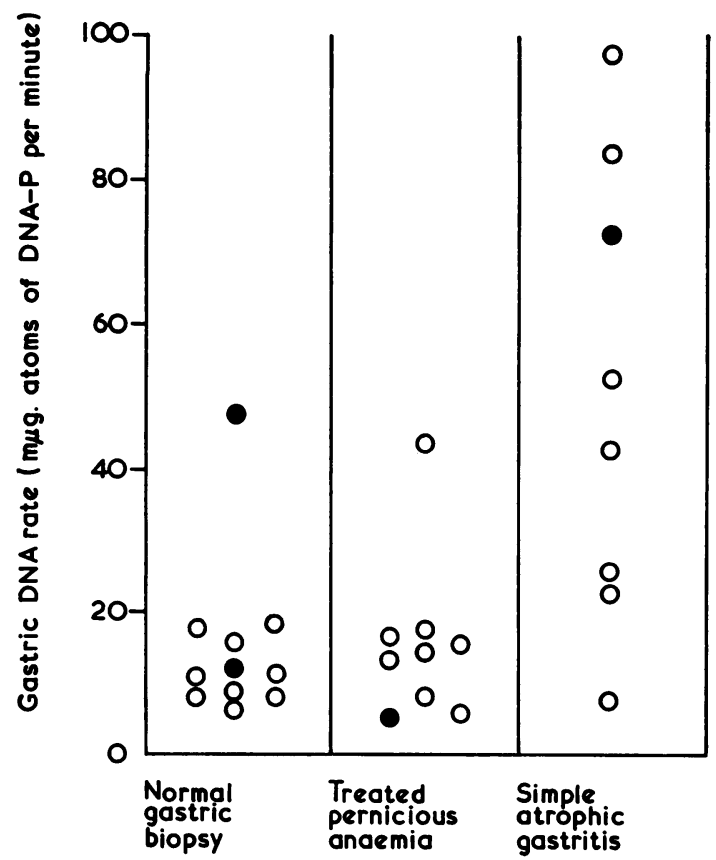

FIG. 2. Gastric DNA rates in 28 subjects. $\bigcirc$, one gastric DNA perfusion test. $\bigcirc$, mean of two gastric DNA perfusion tests (Table I).

four of which were the mean of duplicate tests, are shown in Fig. 2 and Table III. The rates appeared to be unrelated to age, sex, or duration of disease. Two broad patterns emerged:-

1 Most of the patients with a normal gastric mucosa, or with treated pernicious anaemia, had gastric DNA-rates of $18 \mathrm{~m} \mu \mathrm{g}$. atoms DNA-P per minute or less. Only one patient in each of these groups had a rate above this value.

2 The DNA-rates of patients with simple atrophic gastritis had a wider scatter and in most were higher, only one patient having a rate below $18 \mu \mathrm{mg}$. atoms DNA-P per minute. Case 25 had been studied previously by a gastric washout technique involving manual suction and on that occasion had also been found to have a high resting rate of accumulation of DNA (Croft, 1963a).

EFFECT OF VITAMIN $B_{12}$ ON GASTRIC DNA While developing the present technique tests which differed from the final method were performed on patients with pernicious anaemia before and up to seven weeks after starting treatment with vitamin $B_{12}$. It appeared that more DNA was obtained in gastric washings after two or three weeks' treatment with vitamin $B_{12}$ than was obtained before, or up to a week after, starting treatment. Gastric DNA tests 


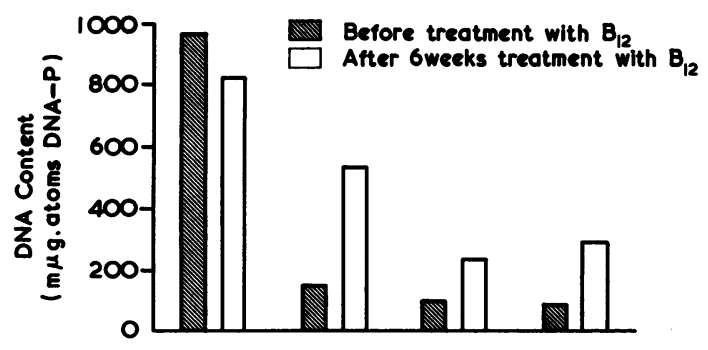

1 In those with a normal mucosa denuded nuclei were usually seen. These were considered to come from the gastric surface epithelial cells because in some areas they were present with degenerate but recognizable gastric columnar cells (Figure 4). Intact squamous cells were not uncommon but although cytologically well preserved, they were relatively few in number compared with the denuded

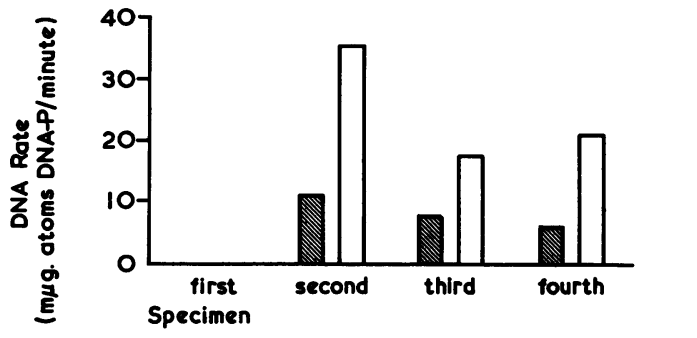

FIG. 3. The result of two gastric DNA tests on the same subject (case 19) with pernicious anaemia before and after treatment with vitamin $B_{12}$. In the top half of the figure the amount of DNA in the specimens is presented as DNA content and in the lower half as the DNA-rate of accumulation. After the resting DNA had been removed in the first and second washings fairly constant DNA-rates were obtained in the third and fourth specimens of the respective tests. The values after treatment were two or three times higher than those before treatment with vitamin $B_{12}$. gastric DNA test before treatment with vitamin $B_{12}$. $\square$, gastric DNA test after six weeks' treatment with vitamin $B_{12}$.

were performed in case 19 before and after treatment for pernicious anaemia. She was not in congestive heart failure and had no cough. Her haemoglobin at the time of the first gastric DNA test before treatment was $7 \cdot 3 \mathrm{~g} . \%$, and her serum $B_{12}$ concentration was $28 \mu \mu \mathrm{g} . / \mathrm{ml}$. After six weeks' treatment with vitamin $B_{12}$ when the haemoglobin was $12 \cdot 1 \mathrm{~g} . \%$ a second test was performed. The pattern of the results of the two tests was similar, large quantities of DNA in both first specimens falling in the third and fourth specimens (Fig. 3). In the first test the gastric DNA-rate derived from the fourth specimen was $5 \mathrm{~m} \mu \mathrm{g}$. atoms DNA-P per minute whereas in the second test in which it was derived from the third specimen it was more than three times this value $(17 \mathrm{~m} \mu \mathrm{g}$. atoms DNA-P per minute). These values contrast with the variation of $\pm 10 \%$ from the mean in other patients having repeated tests (Table I).

GASTRIC CYTOLOGY OF THE THREE CLINICAL GROUPS The cytological appearances were different in the three groups of patients.

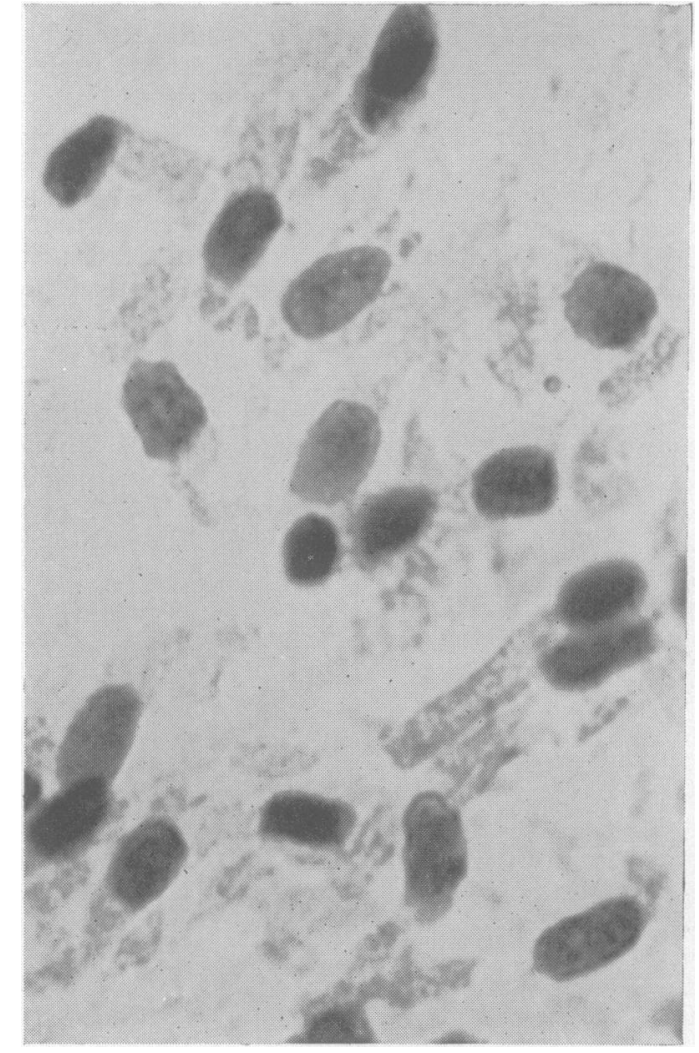

FIG. 4. Degenerating gastric surface epithelial cells and denuded nuclei from the specimen containing the least amount of DNA from a perfusion test in a patient with a normal gastric biopsy (case 7). The nuclei are mainly oval and to some of them denegerate columnar shaped cytoplasm is attached (haematoxylin and eosin, $\times 1,600)$.

nuclei. Polymorphonuclear leucocytes were sometimes present but were not conspicuous.

2 In the patients with treated pernicious anaemia intact gastric surface epithelial cells were seen more commonly. These cells were usually columnar in shape and denuded nuclei were also present. In a few specimens rounded cells of variable size with clumped nuclear chromatin were seen. These had the appearance of abnormal gastric surface epithelial cells (Rubin, 1955; Gibbs, 1962 and 1964; 


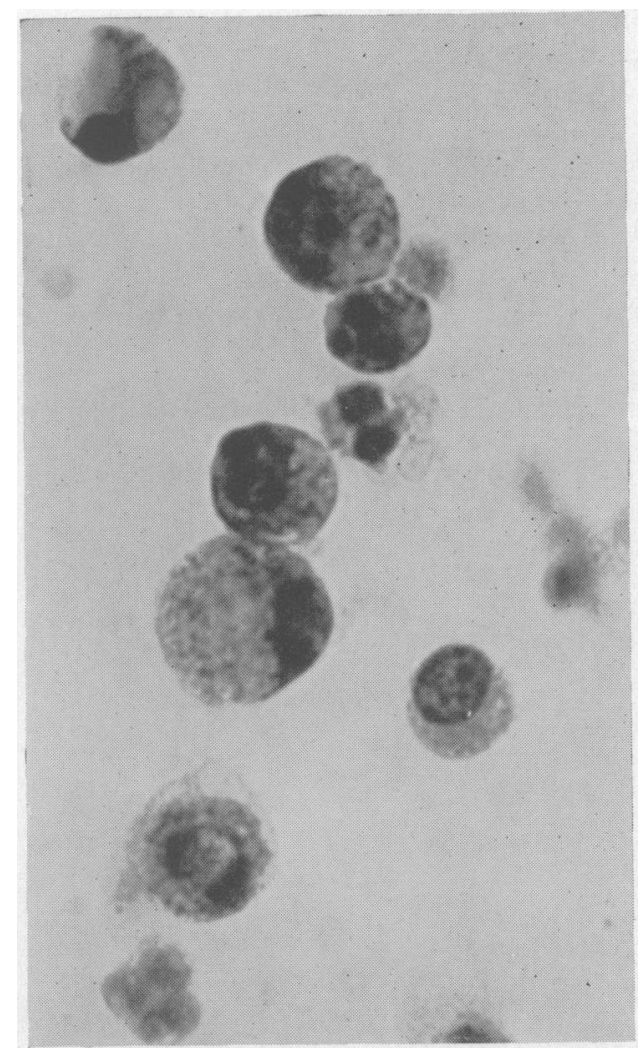

FIG. 5. Round cells of variable size containing nuclei with clumped chromatin from a perfusion test on a patient with simple atrophic gastritis and high gastric DNA-rate (case 25). These cells were considered to be abnormal gastric surface epithelial cells (haematoxylin and eosin, $\times 1,600)$.

Nieburgs and Glass, 1963) and were similar to those seen in patients with simple atrophic gastritis (Figure 5). Polymorphonuclear leucocytes were seen but were not more obvious than in the group with normal gastric mucosa.

3 In the patients with simple atrophic gastritis two patterns were observed.

(a) In the five patients (cases 24-28) with a high gastric DNA-rate (above $40 \mathrm{~m} \mu \mathrm{g}$. atoms DNA-P per minute) both the gastric washings and the slide preparations were macroscopically more cellular. Intact circular cells with nuclei of variable size and containing chromatin clumps were present in large numbers (Fig. 5). These cells were similar to the abnormal gastric surface epithelial cells seen in some specimens from the patients with pernicious anaemia but were more numerous. In some specimens columnar cells were seen but these were relatively few.
Numerous polymorphs were present in association with the abnormal gastric surface epithelial cells.

(b) The appearances of the cellular particles in the three patients (cases 21-23) with a relatively low gastric DNA-rate (below $40 \mathrm{~m} \mu \mathrm{g}$. atoms DNA-P per minute) resembled those of the patients with pernicious anaemia. The specimens contained mainly intact columnar cells and denuded gastric epithelial nuclei. There were a few inflammatory cells and some abnormal gastric surface epithelial cells with nuclear clumping.

These results indicated that both in patients with a normal gastric mucosa and those with treated pernicious anaemia the DNA arose mainly from exfoliated gastric surface epithelial cells. These cells were intact in patients with pernicious anaemia, and denuded of cytoplasm in patients with a normal gastric mucosa (and presumably normal gastric peptic activity). In patients with simple atrophic gastritis the DNA was derived from a combination of gastric surface epithelial cells and inflammatory cells extruded from the gastric mucosa (see below).

GASTRIC HISTOLOGY, DNA-RATES, AND CYTOLOGY High DNA-rates (above $40 \mathrm{~m} \mu \mathrm{g}$. atoms DNA-P per min.) were found in the simple atrophic gastritis patients with grades I, II, and III atrophic gastritis. Inflammatory cells in the superficial and deep mucosa were seen more commonly in the biopsy specimens from patients with simple atrophic gastritis or pernicious anaemia than in those of the control group. Inflammatory cells, usually neutrophils, penetrating the surface epithelium were observed in the biopsy specimens of two patients with pernicious anaemia and in specimens from all but one of the patients with simple atrophic gastritis (Figures 6 and 7). The single exception in the last group was case 21 , the one patient with simple atrophic gastritis, who had a very low gastric DNA-rate (7 m $\mu$ g. DNA-P per min.). Thus inflammatory cells were found in most cases of simple atrophic gastritis both in the gastric biopsy specimens and in the cytological preparations, and they were associated with DNA-rates higher than those in most of the patients with a normal mucosa or pernicious anaemia.

The surface epithelium was composed of regular columnar cells in all the patients of the first two groups (Table III), and in four of those with simple atrophic gastritis. In the other four patients with this condition (cases 24-26 and 28) the surface epithelium was composed wholly, or in part (one patient), of irregular cuboidal cells and these patients were among the five with both the highest DNA-rates in this group and numerous abnormal 


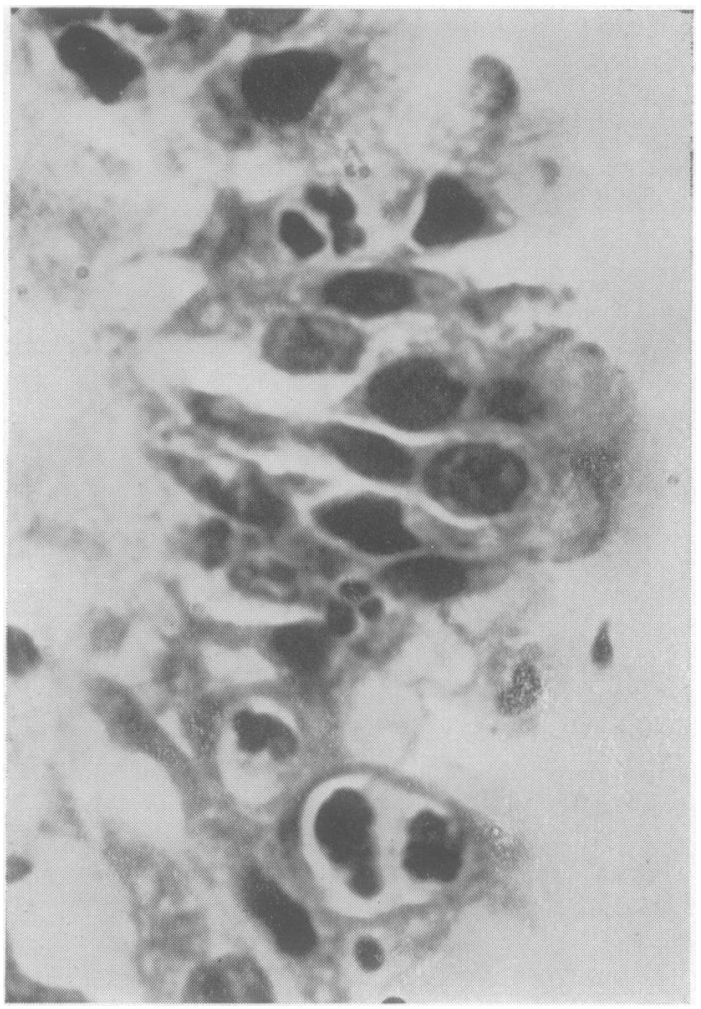

FIG. 6. Gastric biopsy specimen from case 23 showing polymorphonuclear neutrophil cells passing into the surface epithelium of the gastric mucosa (Gibbs, 1964) (haematoxylin and eosin, $\times 1,200$ ).

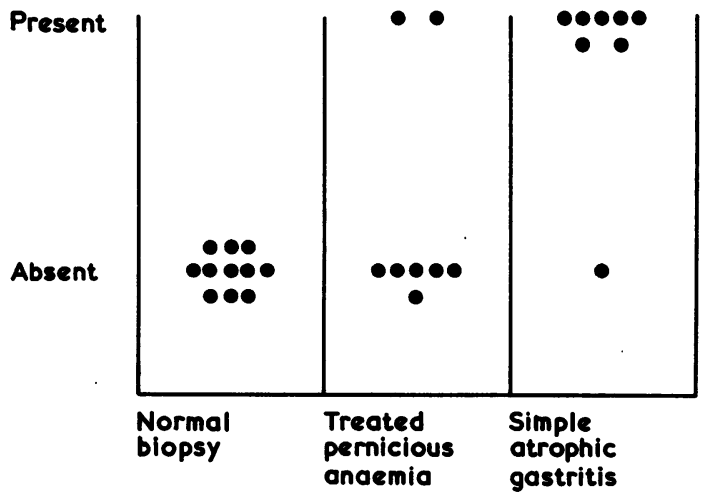

FIG. 7. The presence or absence of inflammatory cells penetrating the surface epithelium in gastric biopsy specimens from eleven patients with a normal mucosa, eight with treated pernicious anaemia, and eight with simple atrophic gastritis. gastric surface epithelial cells in the cytological preparations.

MITOSIS COUNTS OF THE THREE CLINICAL GROUPS These are shown in Table III and Figure 8. In the group with a normal mucosa there was a mean of 0.63 mitoses per 100 surface gastric epithelial cells (S.D. 0.19); in the group with pernicious anaemia there was a mean of 1.4 mitoses (S.D. 0.42) which was significantly higher $(P<0.001)$; in the group with simple atrophic gastritis there was a mean of 1.5 mitoses (S.D. 0.63) which was also significantly

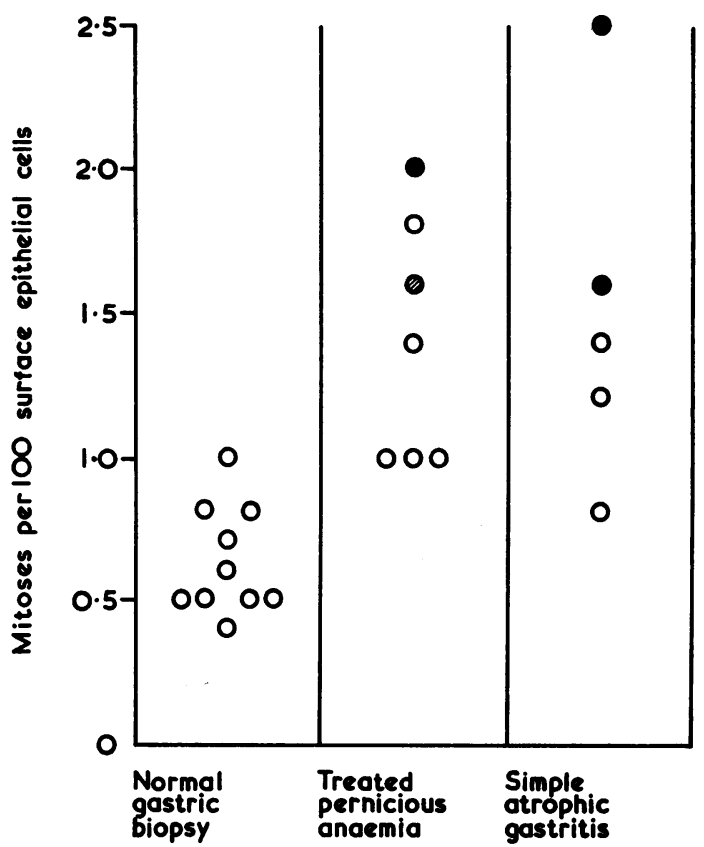

FIG. 8. The distribution of mitosis counts in 22 patients from whom satisfactory gastric biopsy specimens were obtained. $\bigcirc$, mitosis count from area of gastric type epithelium. O, mitosis count from area of intestinal metaplasia. $Y / /$, mean of mitosis counts obtained from an area of gastric type epithelium and an area of intestinal metaplasia.

higher than in the group with normal mucosa $(\mathbf{P}<0.001)$. Three of the four highest mitosis counts were in areas of intestinal metaplasia (two patients with pernicious anaemia and one with simple atrophic gastritis).

SERUM GASTRIC ANTIBODIES None of the patients with normal gastric mucosa had either parietal cell or intrinsic factor antibodies (Table III). Of the nine pernicious anaemia patients all reacted with parietal cells, and six had intrinsic factor antibodies 
in addition to the normal incidence (Roitt, Doniach, and Shapland, 1965). Of the eight patients with simple atrophic gastritis three had parietal cell antibodies and none reacted against intrinsic factor. There was no correlation between DNA-rates and the presence or absence of gastric antibodies.

SECRETOR STATUS AND BLOOD GROUP All but four patients were secretors of $\mathrm{H}$ substance. The gastric DNA-rates of the four non-secretors ranged from low to high values (Table III). In this small series there was no correlation between gastric DNA-rate and blood group or secretor status.

\section{DISCUSSION}

Our results have established that the gastric DNArate gave a measure of cell loss from the gastric mucosa. There was a higher rate of cell loss in most patients with simple atrophic gastritis than in most of those with a normal mucosa, or with pernicious anaemia. There was a higher rate of production of surface epithelial cells, as judged by mitosis counts, in patients with the atrophic mucosa of pernicious anaemia or simple atrophic gastritis. In the one patient with pernicious anaemia tested the DNArate increased significantly after treatment with vitamin $B_{12}$.

New gastric surface epithelial cells are being constantly formed in the bases of the gastric pits. This continuous production of cells is balanced by an equal rate of destruction (Stevens and Leblond, 1953; Crosby, 1961). As the result of an equilibrium between production and loss the histological appearance of the tissue remains unaltered. Epithelial cells in the gut are destroyed by exfoliation into its lumen and it has been calculated that in this process half a pound of cells is lost from the human gastrointestinal surface per day (Leblond and Walker, 1956). It seems probable that DNA in the nuclei of degenerating epithelial cells is also extruded into the gut lumen, although recent work suggests that some of the DNA from degenerating cells may be re-utilized in the epithelium by newly dividing cells (Cutright, 1965). From data on the DNA content of human cells (Davidson et al., 1951) it can be calculated that the rate of loss of cells in our patients with a normal gastric mucosa ranged from 0.26 to 1.75 million cells per minute with a mean of 0.55 million per minute. When related to unit surface area this order of cell loss corresponds reasonably well with that calculated on theoretical grounds for the human small intestine which is a similarly dynamic tissue (Crosby, 1961).

We have found that measurements of the gastric DNA-rate were the same on different occasions in the same patient and our cytological evidence sug- gests that the gastric DNA-rate represents the rate of loss of cells from the gastric mucosa. In patients with a normal mucosa and those with pernicious anaemia the exfoliated cells seemed to be mainly intact or denuded gastric surface epithelial cells. In these patients, if it is assumed that the rate of surface epithelial cell loss is in equilibrium with the rate of production of these cells, measurement of gastric DNA-rate should be an index of the turnover of gastric surface epithelium. In the case of most of the patients with simple atrophic gastritis, however, gastric DNA-rates measured loss of both gastric epithelial cells and inflammatory cells extruded from the gastric mucosa. In this group, therefore, the gastric DNA-rate may not have been as satisfactory a measure of surface epithelial cell loss as in the other two groups, although for reasons stated below, it may still have been an index of surface epithelial cell turnover.

Vitamin $B_{12}$ deficiency affects the synthesis of nucleic acids (Rose and Schweigert, 1952; Smith, 1965) and it has been suggested that this causes a decrease in nucleic acid production and fall in the rate of cell division (Arnstein, 1955). Epithelial tissues in which there is a high rate of cell division might be expected to be especially affected by $B_{12}$ deficiency, and the glossitis of untreated pernicious anaemia which is corrected by $B_{12}$ replacement is probably an example of this (Stone and Spies, 1948). Alterations have been reported in the appearance of the nuclei of exfoliated gastric surface epithelial cells from patients with untreated pernicious anaemia (Graham and Rheault, 1954; Raskin, Kirsner, and Palmer, 1958; Schade, 1960) which suggests that vitamin $B_{12}$ deficiency affects these cells also. The three-fold increase in the rate of accumulation of gastric DNA that was observed in the patient with pernicious anaemia after treatment with vitamin $B_{12}$ (Fig. 3) could be a reflection of an increased rate of turnover of gastric surface epithelial cells. The histological appearance of the atrophic gastric mucosa of pernicious anaemia is considered not to alter materially after treatment with vitamin $B_{12}$ so that if there is an increased rate of production of gastric epithelial cells after treatment then there must be a proportional increase in the rate of cell loss. This concept would be in accord with the finding in rat and human small intestine that alteration of surface epithelial cell production (or turnover) does not necessarily lead to changes in the length or shape of the intestinal villi (Trier, 1962; Conrad, Weintraub, Merrill, and Crosby, 1965).

In normal adults there is only a four-fold range in gastric size and macroscopic surface area (Cox, 1952). Therefore variations in these were unlikely to have accounted for the twenty-fold difference 
between the lowest and highest gastric DNA-rates in our patients. Card and Marks (1960) have estimated total mucosal volume and glandular mucosal volume in partial gastrectomy specimens and from their data an estimate of mucosal epithelial volume can be made by caculation. This figure is probably an index of the number of surface epithelial cells in a stomach and can be shown from their data to have a linear relationship to the maximum acid output over a thirteen-fold range. This implies that there are fewer surface epithelial cells in achlordric than in acid-producing stomachs with a normal mucosa, and it is therefore reasonable to assume that there are fewer of these cells in atrophic than in normal stomachs. As the DNA-rates of the group with pernicious anaemia were much the same as those of the patients with a normal mucosa it could be argued that, per unit of gastric surfacee pithelium, the loss of DNA was higher from these atrophic mucosae.

Although some of the patients with simple atrophic gastritis were not achlorhydric they probably also possessed fewer than normal gastric epithelial cells. It was in this group that in addition to inflammatory cells numerous abnormal surface epithelial cells were noted both in the gastric washings and in the biopsy specimens. Two of the patients with simple atrophic gastritis, who had inflammatory cells penetrating the surface epithelium, and the only two patients with pernicious anaemia showing this phenomenon, had low or relatively low gastric DNA-rates. This, coupled with the cytological appearances, suggested that the high gastric DNArates in simple atrophic gastritis were due not only to loss of inflammatory cells but also to high rates of loss of surface epithelial cells. Therefore we conclude that in the majority of patients with simple atrophic gastritis or the atrophic gastritis of pernicious anaemia the gastric DNA-rates indicated that per unit of gastric epithelium there was a higher turnover of surface epithelial cells than in the patients with a normal gastric mucosa. This conclusion is supported by the finding of higher mitosis rates, which usually (but not always) mean higher rates of cell proliferation, in gastric surface epithelial cells in our patients with pernicious anaemia and simple atrophic gastritis. Areas of intestinal metaplasia in gastric mucosa had especially high mitosis counts indicating that such areas may have had a high cell turnover.

The finding of a high gastric DNA-rate in the patient with pernicious anaemia after treatment with vitamin $B_{12}$ suggests that the rate of production of gastric surface epithelial cells determines, in the resting state, the rate at which these cells are lost from the mucosa.

\section{SUMMARY}

Using a technique of saline perfusion and continuous suction the rate of accumulation of DNA in the stomach was measured in 28 patients. In 11 the gastric mucosa was normal, nine had pernicious anaemia, and eight simple atrophic gastritis.

The gastric DNA-rate was reproducible $( \pm 10 \%)$ and was considered to measure cell loss from the gastric mucosa. The mean rate of loss from normal gastric mucosa was calculated to be approximately half a million cells per minute.

Patients with normal gastric mucosa, and with treated pernicious anaemia had similar gastric DNA-rates but a majority of patients with simple atrophic gastritis had much higher values.

In one patient with pernicious anaemia the gastric DNA-rate after treatment with vitamin $\mathbf{B}_{\mathbf{1 2}}$ was three times the rate observed before treatment.

Significantly higher epithelial mitosis counts were found in gastric biopsies of patients with treated pernicious anaemia and simple atrophic gastritis than in those with normal mucosa.

Gastric DNA-rates, mitosis counts, and histological and cytological findings suggested that the gastric DNA-rate was a measure, in the resting state, of gastric epithelial cell production and loss (or turnover); there was a higher than normal turnover of gastric surface epithelial cells in simple atrophic gastritis and in treated pernicious anaemia.

We are grateful to Dr. D. M. Mollin for kindly estimating the serum $\mathbf{B}_{12}$ levels, and the radioactive vitamin $\mathbf{B}_{\mathbf{1 2}}$ absorption in our patients, and for helpful comments on this work. We thank Dr. A. Knudsen for advice regarding the classification of gastritis; Dr. F. M. Abeles and Dr. D. H. Bodger for performing the barium meal examinations; and Dr. John Laws for his reports on the barium meal examinations he performed on two patients with simple atrophic gastritis. We thank Dr. Denis Gibbs for kindly examining some of the gastric cytology preparations. We are indebted to Dr. P. M. McAllen for allowing us to investigate case 16 .

\section{REFERENCES}

Ardeman, S., and Chanarin, I. (1963). A method for the assay of human gastric intrinsic factor and for the detection and titration of antibodies against intrinsic factor. Lancet, 2, 13501354.

Arnstein, H. R. V. (1955). In The Biochemistry of Vitamin B 12. Biochemical Society Symposium No. 13, p. 94, edited by R. T. Williams. Cambridge University Press.

Baur, S., Roitt, I. M., and Doniach, D. (1965). Characterization of the human gastric parietal cell auto-antigen. Immunology, 8, 62-68.

Belcher, E. H., Anderson, B. B., and Robinson, C. J. (1963). The measurement of gastro-intestinal absorption of Co 58-labelled vitamin B12 by whole body_counting. Nucl.-Med. (Stuttg.), 3, 349-355.

Bertalanffy, F. D., and Nagy, K. (1958). The mitotic activity and 
renewal rate of human dueodenal epithelium. Anat. Rec., 130, 271-272.

Bizzozero, G. (1892), Ueber die schlauchförmigen Drüsen des Magendarmkanals und die Beziehungen ihres Epithels zu dem Oberflächenepithel der Schleimhaut. II. Archiv. mikr. Anat., 40, 325-375.

- (1893). Ueber die schlauchförmigen Drusen des Magendarmkanals und die Beziehungen ihres Epithels zu dem Oberfä chenepithel der Schleimhaut. III. Ibid., 42, 82-152.

Booth, C. C., and Molin, D. L. (1956). Plasma, tissue and urinary radioactivity after oral administration of ${ }^{56} \mathrm{Co}$-labelled vitamin B12. Brit. J. Haemat., 2, 223-236.

Borgström, B., Dahlqvist, A., Lundh, G., and Sjövall, J. (1957). Studies of intestinal digestion and absorption in the human. J. clin. Invest., 36, 1521-1536.

Boyd, W. C., and Shapleigh, E. (1954). Separation of individuals of any blood group into secretors and nonsecretors by use of a plant aggulutinin (lectin). Blood, 9, 1195-1198.

Burton, K. (1956). A study of the conditions and mechanism of the diphenylamine reaction for the colorimetric estimation of deoxyribonucleic acid. Biochem. J., 62, 315-323.

Card, W. I., and Marks, I. N. (1960). The relationship between the acid output of the stomach following 'maximal' histamine stimulation and the parietal cell mass. Clin. Sci., 19, 147-163.

Clarke, C. A., Edwards, J. W., Haddock, D. R. W., Howel-Evans, A. W., McConnell, R. B., and Sheppard, P. M. (1956). ABO blood groups and secretor character in duodenal ulcer. Brit. med. J., 2, 725-731.

Coghill, N. F., and Williams, A. W. (1955) Gastric biopsy with a modified Australian instrument. Ibid., 2, 1111-1114.

Conrad, M. E., Weintraub, L. R., Merrill, B., and Crosby, W. H. (1965). The effect of acetylphenlhydrazine upon epithelial turnover in the small intestine. Amer. J. dig. Dis., 10, 43-46.

Cox, A. J., Jr. (1952). Stomach size and its relation to chronic peptic ulcer. Arch. Path., 54, 407-422.

Creamer, B., Shorter, R. G., and Bamforth, J. (1961). The turnover and shedding of epithelial cells. Part $\mathrm{I}$. The turnover in the gastro-intestinal tract. Part II. The shedding in the small intestine. Gut, 2, 110-118.

Croft, D. N. (1963a). Exfoliative cytology of the stomach after the administration of salicylates. In Salicylates, edited by A. St. J. Dixon, B. K. Martin, M. J. H. Smith, and P. H. N. Wood, pp. 204-207. Churchill, London.

- (1963b). Aspirin and the exfoliation of gastric epithelial cells. Cytological and biochemical observations. Brit. med. J., 2, 897-901.

- , and Lubran, M. (1965). The estimation of deoxyribonucleic acid in the presence of sialic acid: application to analysis of human gastric washings. Biochem. J., 95, 612-620.

Crosby, W. H. (1961). A concept of the pathogenesis of anemia applied to disorders of the intestinal mucosa. Amer. J. dig. Dis., 6, 492-498.

Cutright, D. E. (1965). Cytokinetics and DNA metabolism in the oral mucosa of the rat. Fed. Proc., 24, No. 2, part 1, p. 202.

Davidson, J. N., Leslie, I., and White, J. C. (1951). The nucleic-acid content of the cell. Lancet, 1, 1287-1290.

Dick, G. F. (1941). The bacteriologic examination of the stomach contents in pernicious anemia. Amer. J. dig. Dis., 8, 255-260.

Doll, R., Drane, H., and Newell, A. C. (1961). Secretion of blood group substances in duodenal, gastric and stomal ulcer, gastric carcinoma, and diabetes mellitus. Gut, 2, 352-359.

Friedman, N. B. (1945). Cellular dynamics in the intestinal mucosa: the effect of irradiation on epithelial maturation and migration. J. exp. Med., 81, 553-558.

Gibbs, D. D. (1962). 'Exfoliative cytology of the stomach.' $D . M$. Thesis, Oxford University.

- (1964). The permeation of gastric epithelial cells by leucocytes. Gut, 5, 160-165.

Glass, G. B. J., Boyd, L. J., Gellin, G. A., and Stephanson, L. (1954). Uptake of radioactive vitamin B12 by the liver in humans: test for measurement of intestinal absorption of vitamin B12 and intrinsic factor activity. Arch. Biochem., 51, 251-257.

Graham, R. M., and Rheault, M. H. (1954). Characteristic cellular changes in epithelial cells in pernicious anemia. J. Lab. clin. Med., 43, 235-245.

Hurst, A. F. (1924). An address on Addison's (pernicious) anaemia and subacute combined degeneration of the spinal cord. Brit. med. J., 1, 93-100.

Hutner, S. H., Bach. M. K., and Ross, G. I. M. (1956). A sugar containing basal medium for vitamin B12 assay with Euglena; application to body fluids. J. Protozool., 3, 101-112.
Hyden, S. (1956). A turbidimetric method for the determination of higher polyethylene glycols in biological materials. K. Lantbr. Högsk. Annlr., 22, 139-145.

Irvine, W. J., Davies, S. H., Delamore, I. W., and Williams, A. W. (1962). Immunological relationship between pernicious anaemia and thyroid disease. Brit. med. J., 2, 454-456.

Jeffries, G. H., Hoskins, D. W., and Sleisenger, M. H. (1962). Antibody to intrinsic factor in serum from patients with pernicious anemia. J. clin. Invest., 41, 1106-1115.

Kay, A. W. (1953). Effect of large doses of histamine on gastric secretion of HC1. An augmented histamine test. Brit. med.J., 2, 77-80.

Laws, J. W., and Pitman, R. G. (1960). The radiological features of pernicious anaemia. Brit. J. Radiol., 33, 229-237.

Leblond, C. P., and Messier, B. (1958). Renewal of chief cells and goblet cells in the small intestine as shown by radioautography after injection of thymidine- $\mathrm{H}^{3}$ into mice. Anat. Rec., 132, 247-259.

- and Stevens, C. E. (1948). The constant renewal of the intestinal epithelium in the albino rat. Anat. Rec., 100, 357-377.

_, and Walker, B. E. (1956). Renewal of cell populations. Physiol. Rev., 36, 255-276.

Lipkin, M., Sherlock, P., and Bell, B. (1963). Cell proliferation kinetics in the gastrointestinal tract. II. Cell renewal in stomach, ileum, colon, and rectum. Gastroenterology, 45, 721-729.

MacDonald, W. C., Trier, J. S., and Everett, N. B. (1964). Cell proliferation and migration in the stomach, duodenum, and rectum of man: radioautographic studies. Ibid., 46, 405-417.

Marmur, J. (1961). A procedure for the isolation of deoxyribonucleic acid from micro-organisms. J. molec. Biol., 3, 208-218.

Nieburgs, H. E., and Glass, G. B. J. (1963). Gastric-cell maturation disorders in atrophic gastritis, pernicious anemia, and carcinoma. Amer. J. dig. Dis., 8, 135-159.

Nordgren, B. (1963). The rate of secretion and electrolyte content of normal gastric juice. Acta physiol. scand., 58, suppl. 202.

Raskin, H. F., Kirsner, J. B., and Palmer, W. L. (1958). Cancer of the alimentary tract. III. Exfoliative cytology of the gastro-intestinal tract. In Modern Trends in Gastro-Enterology, 2nd series, edited by F. Avery Jones, pp. 76-91. Butterworth, London.

Roitt, I. M., Doniach, D., and Shapland, C. (1965). Autoimmunity in pernicious anemia and atrophic gastritis. Ann. N.Y. Acad. Sci., 124, 644-656.

Rose, I. A., and Schweigert, B. S. (1952). Effect of vitamin B12 on nucleic acid metabolism of the rat. Proc. Soc. exp. Biol. (N.Y.), 79, 541-544.

Rubin, C. E. (1955). The diagnosis of gastric malignancy in pernicious anemia. Gastroenterology, 29, 563-587.

Schade, R. O. K. (1960). Gastric Cytology: Principles, Methods and Results. Arnold, London.

Schilling, R. F. (1953). Intrinsic factor studies .II. The effect of gastric juice on the urinary excretion of radioactivity after the oral administration of radioactive vitamin B12. J. Lab. clin. Med., 42, 860-866.

Smith, E. L (1965), Vitamin B12, 3rd edition. Methuen, London.

Stevens, C. E., and Leblond, C. P. (1953). Renewal of the mucous cells in the gastric mucosa of the rat. Anat. Rec., 115, 231-245.

Stone, R. E., and Spies, T. D. (1948). The effect of liver extract and vitamin B12 on the mucous membrane lesions of macrocytic anemia. J. Lab. clin. Med., 33, 1019-1023.

Taylor, K. B., Roitt, I. M., Doniach, D., Couchman, K. G., and Shapland, C. (1962). Autoimmune phenomena in pernicious anaemia: gastric antibodies. Brit. med., J., 2, 1347-1352.

Tomenius, J. H. (1947). A study on the gastric sediment. Acta med. scand. 128, suppl. 189.

Trier, J. S. (1962). Morphologic alterations induced by methotrexate in the mucosa of human proximal intestine. I. Serial observations by light microscopy. Gastroenterology, 42, 295-305.

Whiteside, M. G., Mollin, D. L., Coghill, N. F., Williams, A. W., and Anderson, B. (1964). The absorption of radioactive vitamin B12 and the secretion of hydrochloric acid in patients with atrophic gastritis. Gut, 5, 385-399.

Williams, A. W., Edwards, F., Lewis, T. H. C., and Coghill, N. F. (1957). Investigation of non-ulcer dyspepsia by gastric biopsy. Brit. med. J., 1, 372-377.

Wood, I. J., Doig, R. K., Motteram, R., and Hughes, A. (1949). Gastric biopsy. Report on fifty-five biopsies using a new flexible gastric biopsy tube. Lancet, 1, 18-21.

-, Ralston, M., Ungar, B., and Cowling, D. C. (1964). Vitamin B12 deficiency in chronic gastritis. Gut, 5, 27-36. 